\title{
Seasonal effects of 19 plant species on COD removal in subsurface treatment wetland microcosms
}

\author{
Carrie R. Taylor ${ }^{\mathrm{a}}$, Paul B. Hook ${ }^{\mathrm{b}}$, Otto R. Stein ${ }^{\mathrm{c}, *}$, Cathy A. Zabinski ${ }^{\mathrm{d}}$ \\ a Center for Biofilm Engineering and the Department of Land Resources and Environmental Sciences, Montana State University, Bozeman, MT 59717, United States \\ ${ }^{\mathrm{b}}$ Intermountain Aquatics, Driggs, ID 83422 and Center for Biofilm Engineering, Montana State University, Bozeman, MT 59717, United States

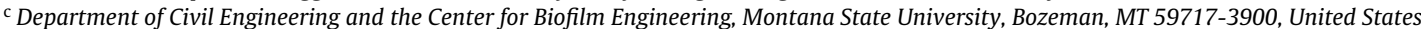 \\ d Department of Land Resources and Environmental Sciences, Montana State University, Bozeman, MT 59717, United States
}

\section{A R T I C L E I N F O}

\section{Article history:}

Received 15 January 2010

Received in revised form 21 May 2010

Accepted 27 May 2010

Available online 7 July 2010

\section{Keywords:}

Constructed wetland

Chemical oxygen demand

Microbial

Sulfate

Temperature

Root zone

\begin{abstract}
A B S T R A C T
Plants have many well-documented influences in treatment wetlands, but differences in individual species' effects on year-round and seasonal performance are poorly understood. In this study, we evaluated plant effects on seasonal patterns of organic carbon removal (measured as COD) and sulfate concentration (used as an indicator of rootzone oxidation) in replicated, batch-loaded, greenhouse microcosms simulating subsurface treatment wetlands. Microcosms were planted with monocultures of 19 plant species or left unplanted as controls, dosed every 20 days with synthetic secondary wastewater, and operated over 20 months at temperatures from 4 to $24{ }^{\circ} \mathrm{C}$. Study-long COD removal averaged $70 \%$ for controls and 70-97\% for individual species. Most species enhanced COD removal significantly and the benefits of plants were greatest at $4-8^{\circ} \mathrm{C}$ because COD removal decreased at low temperatures in controls but displayed limited seasonal variation in planted microcosms. Removal was significantly better at $24^{\circ} \mathrm{C}$ than $4^{\circ} \mathrm{C}$ with two species (Panicum virgatum and Leymus cinereus), significantly poorer with two species (Carex utriculata and Phalaris arundinacea), and did not differ with 15 species. Only one species showed a significant positive correlation between temperature and COD removal (Iris missouriensis, $r=0.67$ ), while two species showed significant negative correlations (better when colder: Carex nebrascensis, $r=-0.67 ; C$. utriculata, $r=-0.93$ ). High COD removal throughout the study was strongly associated with high $\mathrm{SO}_{4} \mathrm{Con}_{-}$ centrations at low temperatures, suggesting that plant performance is related to rootzone oxidation and species' abilities to promote aerobic over anaerobic microbial processes, particularly in winter. Results indicate that improved year-round and cold-season COD removal is common across diverse wetland plant species and novel species can be as good or better than those typically used. Better performing species were largely in the sedge and rush families (Cyperaceae and Juncaceae), while poorer performing species were largely in the grass family (Poaceae).
\end{abstract}

(c) 2010 Elsevier B.V. All rights reserved.

\section{Introduction}

Emergent macrophytes are the most conspicuous features of wetlands, and they play many important roles in the performance of water treatment wetlands (also called constructed wetlands). For example, they decrease flow velocity aiding settling of particulates and adsorption of solutes, transport gases and solutes between above-ground shoots and root zones, take up inorganic compounds and organic pollutants, release oxygen and carbon compounds into the rhizosphere, and influence microbial diversity and activity (Brix, 1997; Tanner, 2001; Stottmeister et al., 2003;

\footnotetext{
* Corresponding author at: Department of Civil Engineering, Montana State University, Bozeman, MT 59717-3900, United States. Tel.: +1 4069946121 ; fax: +1 4069946105 .

E-mail address: ottos@ce.montana.edu(O.R. Stein).
}

Faulwetter et al., 2009). In a review of 35 previously published studies in which plant selection was an experimental factor, Brisson and Chazarenc (2009) showed that in all but one study the presence of plants increased removal of pollutants compared to otherwise similar treatment units (gravel beds or open water "wetlands"), and that most studies found statistically significant differences among the species tested. Comparisons across species that could guide plant selection were hindered by the small number of species evaluated within a given study (typically 2 or 3 , with a maximum of $8)$; limited replication; use of different species, types of treatment wetlands, pollutants, and experimental designs; and lack of mechanistic understanding (Brisson and Chazarenc, 2009).

Because plant growth, physiology, and detritus production vary seasonally, it is reasonable to expect that their effects on treatment processes will vary seasonally and interact with the effects of temperature. Though most of the studies reviewed by Brisson and Chazarenc (2009) focused on temperate regions, few studies 
Table 1

Plant species studied and their wetland indicator status.

\begin{tabular}{|c|c|c|c|}
\hline Species & Common name & Family & Wetland indicator status \\
\hline Carex aquatilis Wahlenb. & Water sedge & Cyperaceae & Obligate Wetland \\
\hline Carex bebbii Olney ex Fernald & Bebb's sedge & Cyperaceae & Obligate Wetland \\
\hline Carex microptera Mack. & Small wing sedge & Cyperaceae & Facultative \\
\hline Carex nebrascensis Dewey & Nebraska sedge & Cyperaceae & Obligate Wetland \\
\hline Carex praegracilis W. Boott & Clustered field sedge & Cyperaceae & Facultative Wetland \\
\hline Carex utriculata Boott & Northwest Territory sedge & Cyperaceae & Obligate Wetland \\
\hline Schoenoplectus acutus (Muhl. ex Bigelow) A. Love \& D. Love & Hardstem bulrush & Cyperaceae & Obligate Wetland \\
\hline Calamagrostis canadensis (Michx.) P. Beauv. & Bluejoint & Poaceae & Facultative Wetland \\
\hline Deschampsia cespitosa (L.) P. Beauv. & Tufted hairgrass & Poaceae & Facultative Wetland \\
\hline Hordeum jubatum L. & Foxtail barley & Poaceae & Facultative \\
\hline Leymus cinereus (Scribn. \& Merr.) A. Love & Basin wildrye & Poaceae & Facultative \\
\hline Panicum virgatum $\mathrm{L}$. & Switchgrass & Poaceae & Facultative \\
\hline Phalaris arundinacea $\mathrm{L}$. & Reed canarygrass & Poaceae & Facultative Wetland \\
\hline Phragmites australis (Cav.) Trin. ex Steud. & Common reed & Poaceae & Facultative Wetland \\
\hline Juncus arcticus Willd. & Arctic rush & Juncaceae & Facultative Wetland \\
\hline Juncus torreyi Coville & Torrey's rush & Juncaceae & Facultative Wetland \\
\hline Typha latifolia $\mathrm{L}$. & Broadleaf cattail & Typhaceae & Obligate \\
\hline Iris missouriensis Nutt. & Rocky Mountain iris & Iridaceae & Facultative Wetland \\
\hline Prunella vulgaris L. & Common selfheal & Lamiaceae & Facultative \\
\hline
\end{tabular}

a Relative degree of association of each species with wetland as ranked by the U.S. Fish and Wildlife Service (1988). Obligate Wetland species are estimated to occur in wetlands $>99 \%$ of the time, Facultative Wetland species $67-99 \%$ of the time, and Facultative species $34-66 \%$ of the time.

of plant effects have simultaneously considered the effects of temperature and season on treatment wetland performance. Those that did generally reported strong interactions between plants and seasonal pollutant removal. For example, Allen et al. (2002) observed no differences in chemical oxygen demand (COD) removal, sulfate $\left(\mathrm{SO}_{4}\right)$ concentration, or redox potential (Eh) between three species and an unplanted control in summer $\left(24^{\circ} \mathrm{C}\right)$, but in winter $\left(4^{\circ} \mathrm{C}\right.$, during plant dormancy) significant differences developed between treatments, with removal greatest in Carex utriculata, followed by Schoenoplectus acutus, Typha latifolia, and then unplanted controls. Seasonal data from the same study found classic, direct temperature dependence only with unplanted controls; Typha wetlands followed a similar trend, but temperature effects were dampened; wetlands planted with Schoenoplectus had minimal seasonal variation; and those planted with Carex displayed a significant inverse relationship between temperature and COD removal (Stein and Hook, 2005). Differences in seasonal patterns of pollutant removal between species have also been observed by Bachand and Horne (2000), Picard et al. (2005), Riley et al. (2005), Kowles-Grove and Stein (2005), Stein et al. (2007) and Yang et al. (2007).

The purpose of this study was to investigate the effects of a wide range of plant species on seasonal patterns of organic matter removal and rootzone oxidation in subsurface treatment wetland microcosms operated at temperatures representative of a coldwinter climate. In addition to evaluating plant effects on COD removal, study goals were to aid plant species selection in temperate climates and elucidate simple mechanisms for differences between species and season. The questions addressed included: Do plants affect seasonal patterns of COD removal as well as yearround average COD removal? Are such plant effects common for many species, and is their magnitude species-specific? Are plant effects more prevalent in certain groups of species? And is variation in COD removal with different plant species and at different temperatures related to sulfate, an indicator of rootzone oxidation status?

\section{Methods}

We used controlled greenhouse experiments with replicated, batch-loaded microcosms to compare plant effects across 19 species over a 20 -month period. COD was used as a measure of organic matter removal, and sulfate concentration was used as a measure of rootzone oxidation. Temperature was varied seasonally from 4 to $24^{\circ} \mathrm{C}$. The experimental design eliminated variation in many factors previously identified as confounding assessments of plant effects on performance (Brisson and Chazarenc, 2009): wastewater composition, loading rate and environmental conditions were identical; unplanted control units were included; and most importantly, plants were allowed to grow in wastewater for six months before experiments began, minimizing start-up effects.

\subsection{Species selection}

A diverse selection of sedges, rushes, grasses, and forbs was chosen for comparison (Table 1). Plants ranged from Facultative to Obligate Wetland species (U.S. Fish and Wildlife Service, 1988), represented several families, and included several of the species that are used most widely in treatment wetlands as well as plants that are used less often (Wallace and Knight, 2006; Kadlec and Wallace, 2009).

\subsection{Wastewater treatment and chemistry}

Plant effects on COD removal were tested using wetland microcosms operated in a controlled environment over 20 months. The experiment was conducted in a greenhouse at the Plant Growth Center at Montana State University in Bozeman, $\mathrm{MT}\left(46^{\circ} \mathrm{N}, 111^{\circ} \mathrm{W}\right)$. Three replicates of unplanted controls and monocultures of each species were planted in model subsurface wetlands consisting of $15 \mathrm{~cm}$ diameter by $30 \mathrm{~cm}$ tall polyvinyl chloride columns filled with $1-5 \mathrm{~mm}$ gravel. Porosity of the columns ranged from $29 \%$ to $40 \%$. From June 20, 2006, through February 12, 2008, greenhouse temperature was changed every 60 days to mimic natural seasonal cycles; the temperature sequence was $24,16,8,4,8,16,24,16$, 8 , and $4{ }^{\circ} \mathrm{C}$. Data for the first period (July 2006) are not presented because they were highly erratic, apparently due to start-up effects. Supplemental lighting was not used. Patterns of natural light and controlled temperature induced normal seasonal cycles of plant dormancy and growth. Season and temperature were confounded in the study design and are used interchangeably.

To simulate batch operation in subsurface flow treatment wetlands, microcosms were drained and filled every 20 days with synthetic wastewater simulating secondary domestic effluent. The wastewater was made with $0.58 \mathrm{mM}$ sucrose $\left(\mathrm{C}_{12} \mathrm{H}_{22} \mathrm{O}_{11}\right), 0.73 \mathrm{mM}$ 

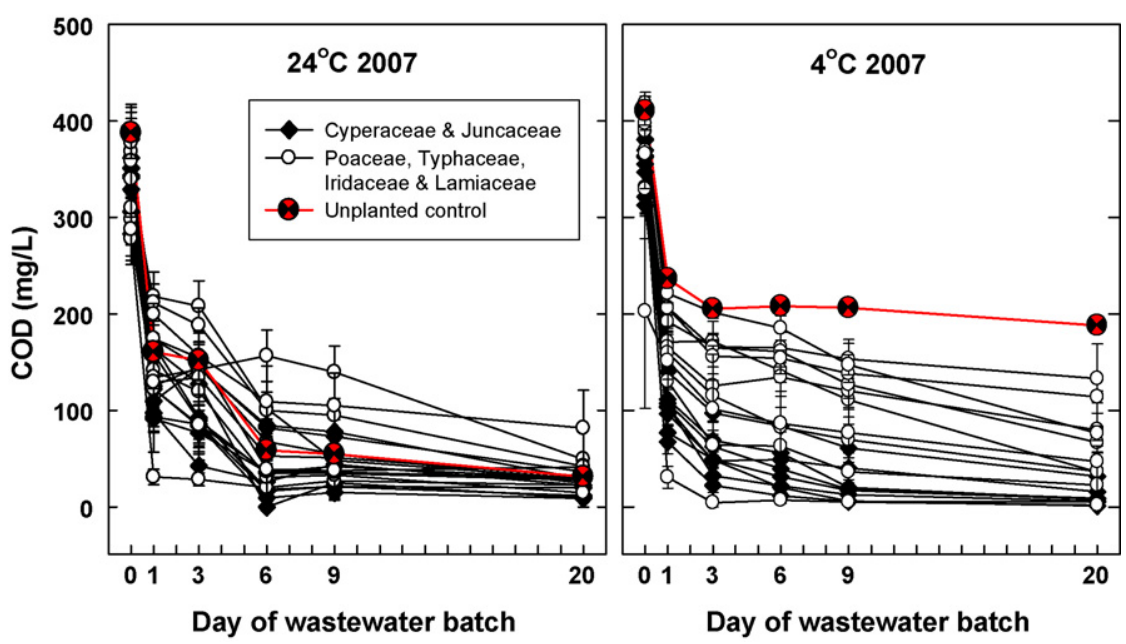

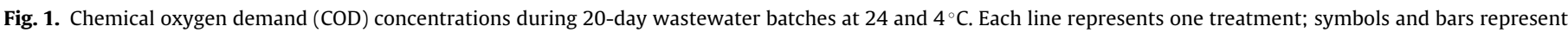
means of three replicates \pm one standard error. Influent COD $=478 \mathrm{mg} / \mathrm{L}$ at $24{ }^{\circ} \mathrm{C}$ and $492 \mathrm{mg} / \mathrm{L}$ at $4{ }^{\circ} \mathrm{C}$.

Primatone (hydrolyzed meat protein, Sigma Chemical Company), $10.7 \mathrm{mM} \mathrm{NH}{ }_{4} \mathrm{Cl}, 0.25 \mathrm{~K}_{2} \mathrm{HPO}_{4}, 0.25 \mathrm{mM} \mathrm{MgSO}_{4}, 0.16 \mathrm{mM}$ $\mathrm{H}_{3} \mathrm{BO}_{3}, 0.05 \mathrm{mM} \mathrm{MnSO}_{4}, 0.03 \mathrm{mM} \mathrm{ZnSO}_{4}, 0.02 \mathrm{mM} \mathrm{Na}_{2} \mathrm{MoO}_{4}$, $0.01 \mathrm{mM} \mathrm{CaCl} 2,0.01 \mathrm{mM} \mathrm{KI}, 3.2 \mu \mathrm{M} \mathrm{CuSO}_{4}$, and $1.0 \mu \mathrm{M} \mathrm{FeCl}$; influent wastewater had $490 \pm 4.3 \mathrm{mg} / \mathrm{L} \mathrm{COD}, 0.8 \pm 0.1 \mathrm{mg} / \mathrm{L} \mathrm{NO}_{3}$, $8 \pm 0.3 \mathrm{mg} / \mathrm{L} \mathrm{PO}_{4}$, and $14 \pm 0.5 \mathrm{mg} / \mathrm{L} \mathrm{SO}_{4}$. Pollutant concentrations and loading rates for treatment wetlands receiving domestic wastewater vary widely, and the wastewater composition and COD loading rate $(33 \mathrm{~kg} / \mathrm{ha}$ day) used here are well within typical observed and recommended ranges (Kadlec and Wallace, 2009; USEPA, 2000). The specific organic constituents (sucrose and Primatone) comprising most of COD were chosen for their consistent composition, which provided uniform wastewater throughout the study. A standpipe supplied fresh water to replace evaporative losses and maintain the water level just below the gravel surface; this ensured that water volume was constant and changes in wastewater constituents resulted from treatment processes, not evaporation or dilution.

Chemical oxygen demand, sulfate concentrations, and redox potential (not reported here) were measured to evaluate effects of plants and season on wastewater treatment (COD removal) and indirect indicators of rootzone oxidation $\left(\mathrm{SO}_{4}\right.$ and $\left.\mathrm{Eh}\right)$. During the third 20-day wastewater batch of each 60-day temperature period, water was collected from the wastewater mixing tank before dosing the microcosms and from the microcosms on the sixth day of the batch. During 4 and $24^{\circ} \mathrm{C}$ batches, $\mathrm{COD}$ and $\mathrm{SO}_{4}$ were also measured immediately after dosing the microcosms (day 0) and on days 1,3,9, and 20. The choice of day 6 to represent water treatment throughout the study was based on analysis of nearly 200 time series in previous work using the same methods, which showed that results for day 6 are similar to those for days 3-20 and result in essentially the same inferences about effects of plants and seasons (Allen et al., 2002; Stein et al., 2006, 2007). This is confirmed by results for 4 and $24^{\circ} \mathrm{C}$ batches presented below. Microcosm water samples were collected via a vinyl tube with an intake at $15 \mathrm{~cm}$ depth. Chemical oxygen demand was measured colorimetrically (dichromate test, $0-1500 \mathrm{mg} / \mathrm{L}$ COD range, Hach Co., Loveland, CO), and $\mathrm{SO}_{4}$ was measured by ion chromatography (Dionex Corp., Sunnyvale, CA).

Effects of plants and seasons on day-6 COD and $\mathrm{SO}_{4}$ concentrations were tested statistically using a significance level of $p \leq 0.05$. Plant species were compared to controls within each batch using analysis of variance (ANOVA) and planned contrasts. Seasonal temperature effects on $\mathrm{COD}$ and $\mathrm{SO}_{4}$ were analyzed for each species in two ways: 4 and $24^{\circ} \mathrm{C}$ batches were compared using repeated mea- sures ANOVA, and relationships with temperature (across batches) were quantified with Pearson's correlation coefficient.

\section{Results}

The time series for COD removal within the 4 and $24^{\circ} \mathrm{C}$ batches shown in Fig. 1 illustrate several key features of COD results. First, data followed the typical time course seen in treatment wetlands, with rapid exponential decay over days 0-3 followed by a plateau with relatively constant residual COD or very gradual decline through day 20 . This was true at both 4 and $24^{\circ} \mathrm{C}$. Second, when differences among plant species and batches occurred, they generally emerged by day 1 or 3 and persisted through day 20. Consequently, day- 6 results were representative of the entire period after the rapid decay phase (Taylor, 2009; correlations between data for day 6 and days 3,9 , and 20 were $r=0.92-0.99$ at $4{ }^{\circ} \mathrm{C}$ and $r=0.76-0.97$ at $24^{\circ} \mathrm{C}$ ). Finally, effects of plants on COD removal relative to unplanted controls were stronger and more consistent at 4 than $24^{\circ} \mathrm{C}$. At $4^{\circ} \mathrm{C}$, virtually all COD values for planted microcosms were lower than those for controls; at $24^{\circ} \mathrm{C}$, half of COD values for planted microcosms were lower than control average and half were higher. These seasonal differences in plant effects mainly reflected a sharp reduction in COD removal in controls from 93\% on day 20 at $24{ }^{\circ} \mathrm{C}$ to $62 \%$ at $4{ }^{\circ} \mathrm{C}$.

Viewed across all seasonal batches, COD removal in unplanted controls generally decreased at colder temperatures as expected, but temperature had surprisingly little effect on COD removal in planted microcosms (Fig. 2, Table 2). In unplanted microcosms COD removal was relatively high at $16{ }^{\circ} \mathrm{C}$ in $2006(92 \%)$ and at $24{ }^{\circ} \mathrm{C}$ in 2007 (88\%), but ranged between 58\% and 69\% during all other batches at 4,8 , and $16^{\circ} \mathrm{C}$. Removal in controls was significantly less at $4{ }^{\circ} \mathrm{C}$ than $24^{\circ} \mathrm{C}$ (Table 2) and displayed a strong, positive relationship with temperature (Table 3 ).

In contrast to the controls, planted microcosms showed limited seasonal variation in COD removal (Fig. 2). No significant differences were found between the coldest and warmest temperatures with 15 species (Table 2). Microcosms planted with $L$. cinereus and $P$. virgatum had significantly lower COD removal at 4 than $24^{\circ} \mathrm{C}$, while $C$. utriculata and $P$. arundinacea had significantly higher removal at $4{ }^{\circ} \mathrm{C}$. Three species showed significant correlations between COD removal and temperature, but removal increased with temperature only in microcosms with I. missouriensis (Table 3). Removal actually decreased as temperature increased with $C$. nebrascensis and C. utriculata. For a large majority of species, 


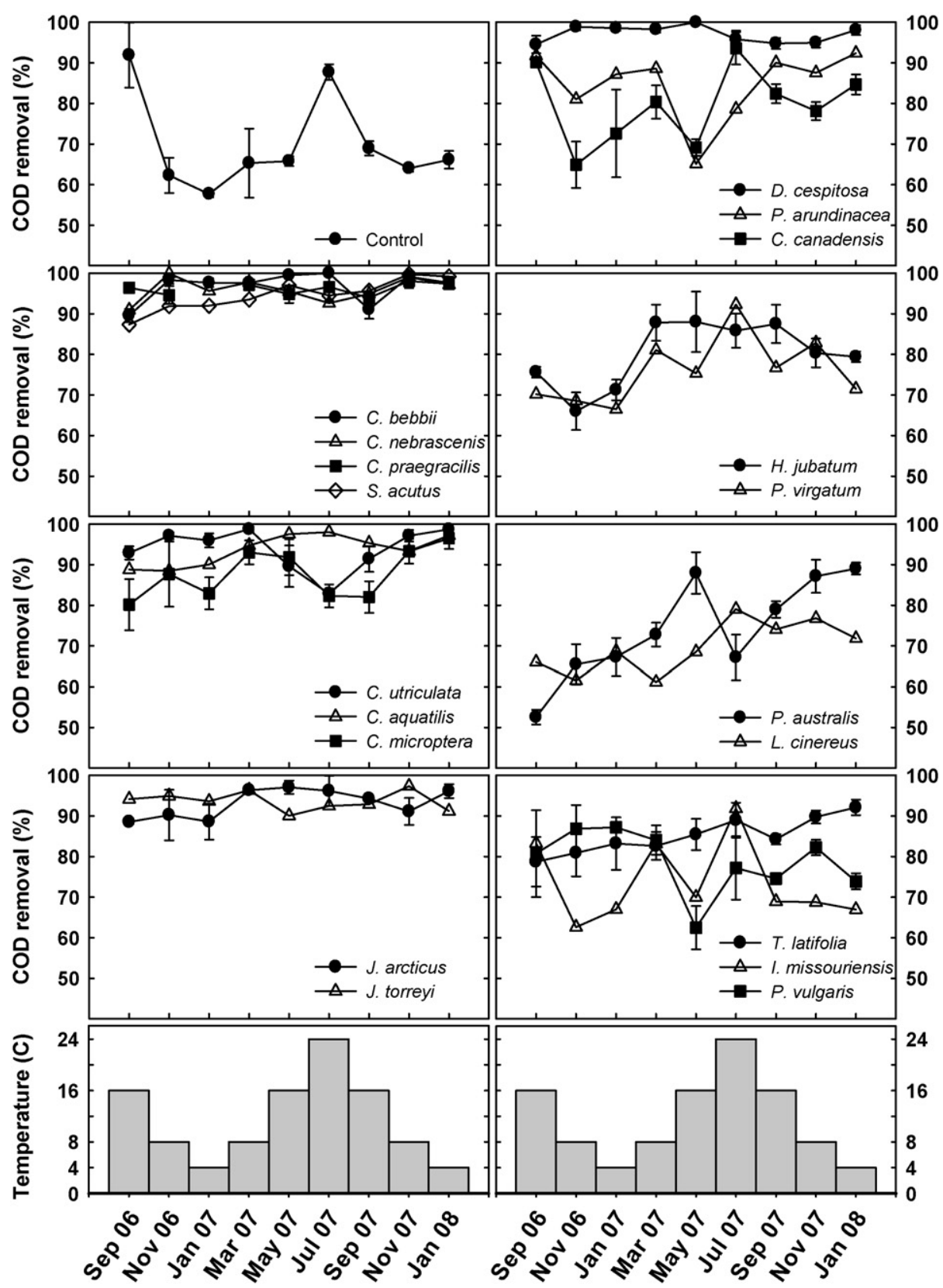

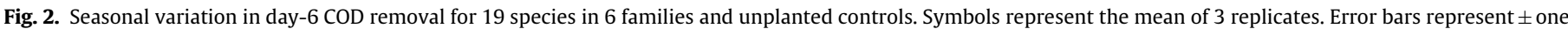
standard error.

COD was relatively constant across temperatures, though some were erratic among batches and/or followed a study-long upward trend.

Differences in COD removal between the unplanted controls and planted microcosms were generally more common and larger at cold temperatures (Fig. 1 and Table 3). During the two batches in which controls had relatively high removal $\left(16^{\circ} \mathrm{C}\right.$ in 2006 and $24^{\circ} \mathrm{C}$ in 2007), there were few significant plant effects. In each of the other seven batches, between 12 and 18 species removed significantly more COD than controls. Overall, plant effects were greater at lower temperatures. At 4 and $8{ }^{\circ} \mathrm{C}$, when differences were statistically significant, planted microcosms removed 25-30\% more COD on average than unplanted controls; at $16^{\circ} \mathrm{C}$, significant differences between planted and unplanted microcosms were $<20 \%$.

Study-long average COD removal ranged from $70 \%$ to $97 \%$ in planted microcosms (Table 2 ). Species rankings were similar across seasons because species with the highest COD removal at cold temperatures generally had slightly higher than average removal at warm temperatures and tended to display less seasonal variation (Fig. 3). COD removal was consistently high across all seasons (83-100\% for individual batches) for five of the six sedges $(C$. aquatilis, C. bebbii, C. nebrascensis, C. praegracilis, and C. utriculata), both species of Juncus, S. acutus, and D. cespitosa (Fig. 2). Study-long COD removal averaged $\geq 93 \%$ for each of these species. Removal was more variable for the other ten species, ranging from $53 \%$ to $94 \%$ for different species and batches; study-long average COD removal was $70-88 \%$ for these species. Five species showed significant upward trends over the course of the study $\left(R^{2}=0.50-0.84\right)$ such that the average values reported in Table 2 may understate their ultimate potential to enhance COD removal. However, increasing COD removal had little effect on species' relative rankings. 
Table 2

COD removal in wetland microcosms as percent reduction relative to influent wastewater ( \pm standard error).

\begin{tabular}{|c|c|c|c|c|c|c|c|c|c|c|}
\hline & $16^{\circ} \mathrm{C} 2006^{\mathrm{b}}$ & $8^{\circ} \mathrm{C} 2006$ & $4^{\circ} \mathrm{C} 2007$ & $8^{\circ} \mathrm{C} 2007$ & $16^{\circ} \mathrm{C} 2007$ & $24^{\circ} \mathrm{C} 2007$ & $16^{\circ} \mathrm{C} 2007$ & $8^{\circ} \mathrm{C} 2007$ & $4^{\circ} \mathrm{C} 2008$ & $\begin{array}{l}\text { Study-long } \\
\text { average }^{c}\end{array}$ \\
\hline D. cespitosa & $95 \pm 2$ & $99 \pm 1 \uparrow$ & $99 \pm 1 \uparrow$ & $98 \pm 1 \uparrow$ & $100 \pm 0 \uparrow$ & $96 \pm 2$ & $95 \pm 1 \uparrow$ & $95 \pm 1 \uparrow$ & $98 \pm 1 \uparrow$ & $97 \pm 2$ \\
\hline C. bebbii & $90 \pm 2$ & $98 \pm 1 \uparrow$ & $98 \pm 1 \uparrow$ & $98 \pm 0 \uparrow$ & $99 \pm 0 \uparrow$ & $100 \pm 0 \uparrow$ & $91 \pm 2 \uparrow$ & $99 \pm 0 \uparrow$ & $98 \pm 1 \uparrow$ & $97 \pm 1$ \\
\hline C. nebrascensis & $91 \pm 2$ & $100 \pm 0 \uparrow$ & $96 \pm 2 \uparrow$ & $98 \pm 1 \uparrow$ & $96 \pm 3 \uparrow$ & $93 \pm 3$ & $95 \pm 0 \uparrow$ & $99 \pm 0 \uparrow$ & $97 \pm 1 \uparrow$ & $96 \pm 1$ \\
\hline C. praegracilis & $96 \pm 1$ & $95 \pm 2 \uparrow$ & NA & $97 \pm 1 \uparrow$ & $95 \pm 2 \uparrow$ & $97 \pm 3$ & $94 \pm 1 \uparrow$ & $98 \pm 2 \uparrow$ & $97 \pm 1 \uparrow$ & $96 \pm 1$ \\
\hline S. acutus & $87 \pm 3$ & $92 \pm 5 \uparrow$ & $92 \pm 2 \uparrow$ & $94 \pm 2 \uparrow$ & $97 \pm 1 \uparrow$ & $94 \pm 2$ & $96 \pm 1 \uparrow$ & $100 \pm 0 \uparrow$ & $99 \pm 0 \uparrow$ & $95 \pm 2$ \\
\hline C. aquatilis & $89 \pm 1$ & $88 \pm 7 \uparrow$ & $90 \pm 3 \uparrow$ & $95 \pm 2 \uparrow$ & $98 \pm 0 \uparrow$ & $98 \pm 0$ & $95 \pm 0 \uparrow$ & $93 \pm 1 \uparrow$ & $97 \pm 1 \uparrow$ & $94 \pm 2$ \\
\hline C. utriculata ${ }^{*}, \mathrm{a}$ & $93 \pm 2$ & $97 \pm 1 \uparrow$ & $96 \pm 2 \uparrow$ & $99 \pm 1 \uparrow$ & $90 \pm 5 \uparrow$ & $83 \pm 1$ & $91 \pm 3 \uparrow$ & $97 \pm 1 \uparrow$ & $99 \pm 1 \uparrow$ & $94 \pm 2$ \\
\hline J. torreyi & $94 \pm 1$ & $95 \pm 3 \uparrow$ & $94 \pm 2 \uparrow$ & $96 \pm 0 \uparrow$ & $90 \pm 2 \uparrow$ & $92 \pm 6$ & $93 \pm 2 \uparrow$ & $97 \pm 2 \uparrow$ & $91 \pm 2 \uparrow$ & $94 \pm 1$ \\
\hline J. arcticus & $89 \pm 0$ & $90 \pm 6 \uparrow$ & $89 \pm 4 \uparrow$ & $96 \pm 0 \uparrow$ & $97 \pm 2 \uparrow$ & $96 \pm 4$ & $94 \pm 0 \uparrow$ & $91 \pm 3 \uparrow$ & $96 \pm 2 \uparrow$ & $93 \pm 2$ \\
\hline C. microptera & $80 \pm 6 \downarrow$ & $88 \pm 8 \uparrow$ & $83 \pm 4 \uparrow$ & $93 \pm 3 \uparrow$ & $92 \pm 4 \uparrow$ & $82 \pm 3$ & $82 \pm 4 \uparrow$ & $93 \pm 3 \uparrow$ & $96 \pm 3 \uparrow$ & $88 \pm 2$ \\
\hline P. arundinacea ${ }^{*}$ & $92 \pm 1$ & $81 \pm 4 \uparrow$ & $87 \pm 1 \uparrow$ & $89 \pm 1 \uparrow$ & $65 \pm 3$ & $79 \pm 4$ & $90 \pm 4 \uparrow$ & $88 \pm 2 \uparrow$ & $92 \pm 4 \uparrow$ & $85 \pm 3$ \\
\hline T. latifolia & $79 \pm 6 \downarrow$ & $81 \pm 6 \uparrow$ & $83 \pm 6 \uparrow$ & $83 \pm 3 \uparrow$ & $85 \pm 4 \uparrow$ & $89 \pm 4$ & $84 \pm 1 \uparrow$ & $90 \pm 2 \uparrow$ & $92 \pm 2 \uparrow$ & $85 \pm 2$ \\
\hline C. canadensis & $90 \pm 1$ & $65 \pm 6$ & $73 \pm 11$ & $80 \pm 4 \uparrow$ & $69 \pm 2$ & $94 \pm 4$ & $82 \pm 2 \uparrow$ & $78 \pm 2 \uparrow$ & $85 \pm 2 \uparrow$ & $80 \pm 4$ \\
\hline H. jubatum & $76 \pm 1 \downarrow$ & $66 \pm 5$ & $71 \pm 3$ & $88 \pm 4 \uparrow$ & $88 \pm 7 \uparrow$ & $86 \pm 4$ & $87 \pm 5 \uparrow$ & $80 \pm 4 \uparrow$ & $79 \pm 1 \uparrow$ & $80 \pm 2$ \\
\hline P. vulgaris & $81 \pm 11$ & $87 \pm 6 \uparrow$ & $87 \pm 1 \uparrow$ & $84 \pm 4 \uparrow$ & $62 \pm 5$ & $77 \pm 8$ & $75 \pm 1$ & $82 \pm 2 \uparrow$ & $74 \pm 2$ & $79 \pm 3$ \\
\hline P. virgatum ${ }^{*}$ & $70 \pm 6 \downarrow$ & $69 \pm 4$ & $66 \pm 3$ & $81 \pm 5 \uparrow$ & $75 \pm 4$ & $92 \pm 2$ & $77 \pm 6 \uparrow$ & $83 \pm 3 \uparrow$ & $71 \pm 3$ & $76 \pm 3$ \\
\hline P. australis & $53 \pm 2 \downarrow$ & $65 \pm 5$ & $67 \pm 5$ & $73 \pm 3$ & $88 \pm 5 \uparrow$ & $67 \pm 6 \downarrow$ & $79 \pm 2 \uparrow$ & $87 \pm 4 \uparrow$ & $89 \pm 1 \uparrow$ & $74 \pm 3$ \\
\hline I. missouriensis & $83 \pm 6$ & $63 \pm 4$ & $67 \pm 5$ & $83 \pm 2 \uparrow$ & $70 \pm 4$ & $92 \pm 1$ & $69 \pm 2$ & $69 \pm 0$ & $67 \pm 3$ & $74 \pm 3$ \\
\hline L. cinereus ${ }^{*}$ & $66 \pm 5 \downarrow$ & $62 \pm 5$ & $69 \pm 2$ & $61 \pm 3$ & $69 \pm 3$ & $79 \pm 2$ & $74 \pm 1$ & $77 \pm 3 \uparrow$ & $72 \pm 1$ & $70 \pm 2$ \\
\hline Control $^{*}$ & $92 \pm 1$ & $62 \pm 4$ & $58 \pm 1$ & $65 \pm 9$ & $66 \pm 1$ & $88 \pm 2$ & $69 \pm 2$ & $64 \pm 1$ & $66 \pm 2$ & $70 \pm 3$ \\
\hline
\end{tabular}

a COD removal differed significantly between $4{ }^{\circ} \mathrm{C}$ and $24^{\circ} \mathrm{C}$ in treatments with an asterisk.

b Within each column, values followed by $(\uparrow)$ had significantly higher COD removal than the control; values followed ( $\downarrow)$ by had significantly lower COD removal than the control ( $p<0.05$, planned contrast within ANOVA).

c Treatments are sorted in descending order of study-long average COD removal calculated as the mean of all nine batches.

* Repeated measures ANOVA $(p<0.05)$.

Temperature affected $\mathrm{SO}_{4}$ concentrations much more than COD (Fig. 3). At $24^{\circ} \mathrm{C}, \mathrm{SO}_{4}$ concentrations were uniformly low for all species and controls (generally $\leq 1.2 \mathrm{mg} / \mathrm{L}$ on days $3-20$ ). At $4{ }^{\circ} \mathrm{C}$, $\mathrm{SO}_{4}$ differed strongly among species, with day-6 concentrations ranging from 0.2 to $14.6 \mathrm{mg} / \mathrm{L}$. For the majority of species, $\mathrm{SO}_{4}$ concentration increased significantly as temperature decreased (Table 3). Significant negative correlations $(r \leq-0.63)$ between temperature and $\mathrm{SO}_{4}$ were found for all sedges and rushes and $S$.

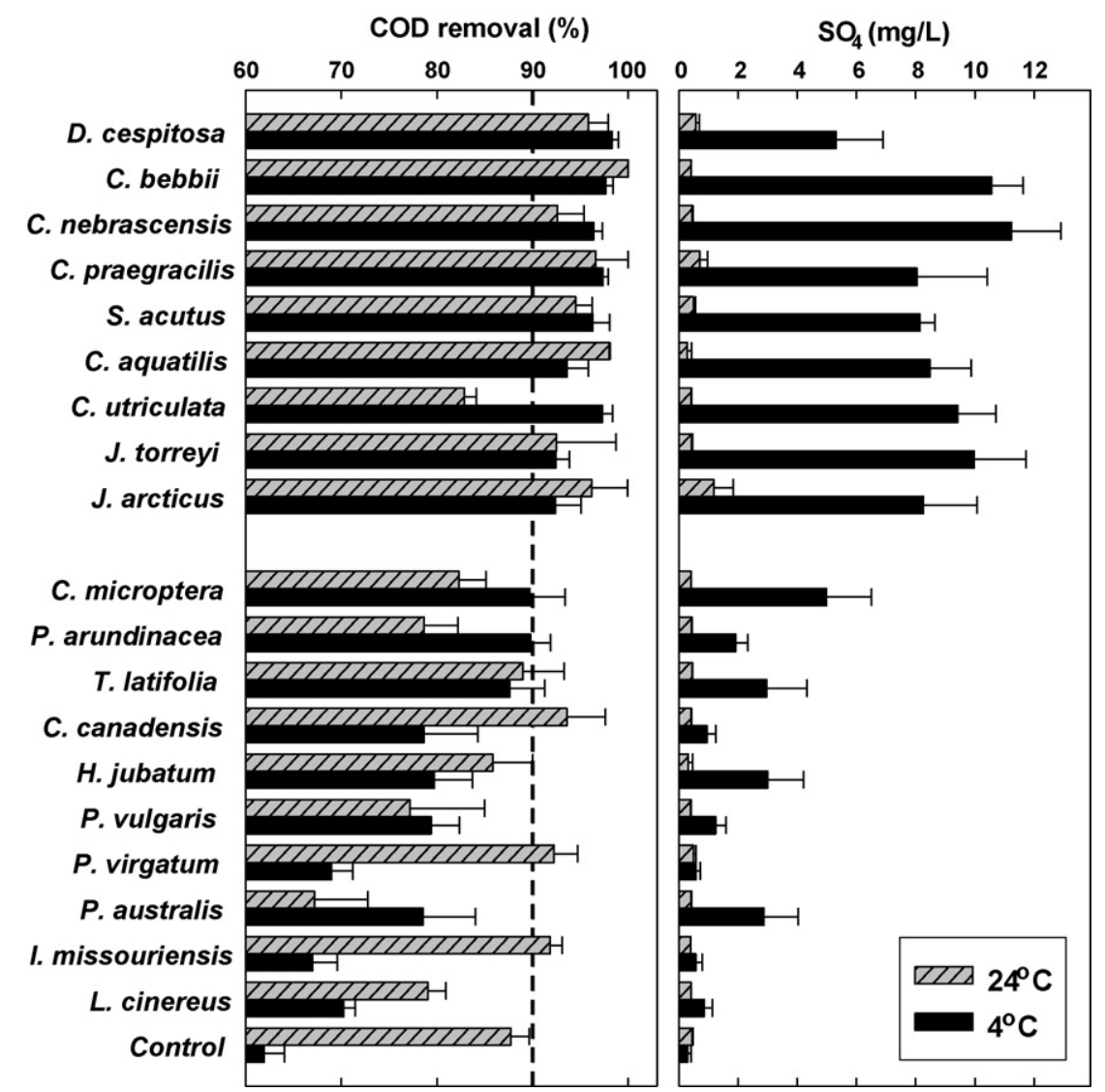

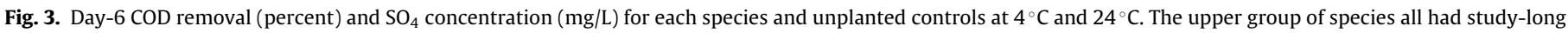

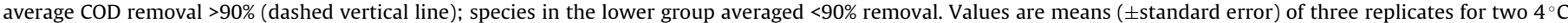
batches in 2007 and 2008 and one $24^{\circ} \mathrm{C}$ batch in 2007 . Influent $\mathrm{SO}_{4}$ averaged $13.0 \mathrm{mg} / \mathrm{L}$ for these batches. 
Table 3

Correlation coefficients for temperature versus percent COD removal and temperature versus sulfate concentration. Species are sorted in descending order of study-long average COD removal.

\begin{tabular}{|c|c|c|}
\hline & COD removal ${ }^{\mathrm{a}}$ & $\mathrm{SO}_{4}^{\mathrm{a}}$ \\
\hline D. cespitosa & -0.40 & $-0.78^{*}$ \\
\hline C. bebbii & -0.20 & $-0.84^{*}$ \\
\hline C. nebrascensis & $-0.67^{*}$ & $-0.79 *$ \\
\hline C. praegracilis & -0.26 & $-0.77^{*}$ \\
\hline S. acutus & -0.20 & $-0.77^{*}$ \\
\hline C. aquatilis & +0.37 & $-0.73^{*}$ \\
\hline C. utriculata & $-0.93^{*}$ & $-0.85^{*}$ \\
\hline J. torreyi & -0.37 & $-0.79^{*}$ \\
\hline J. arcticus & +0.32 & $-0.77^{*}$ \\
\hline C. microptera & -0.55 & $-0.63^{*}$ \\
\hline P. arundinacea & -0.40 & $-0.69 *$ \\
\hline T. latifolia & -0.10 & -0.30 \\
\hline C. canadensis & +0.49 & -0.14 \\
\hline H. jubatum & +0.51 & -0.33 \\
\hline P. vulgaris & -0.45 & -0.25 \\
\hline P. virgatum & +0.60 & +0.40 \\
\hline P. australis & -0.24 & -0.48 \\
\hline I. missouriensis & $+0.67^{*}$ & +0.05 \\
\hline L. cinereus & +0.40 & -0.32 \\
\hline Control & $+0.77^{*}$ & +0.35 \\
\hline
\end{tabular}

a Correlation coefficients followed by asterisks $\left({ }^{*}\right)$ are significantly different from zero.

acutus, $D$. cespitosa, and $P$. arundinacea; mean $\mathrm{SO}_{4}$ concentration at $4{ }^{\circ} \mathrm{C}$ exceeded $5 \mathrm{mg} / \mathrm{L}$ for all of these species except $P$. arundinacea $(2 \mathrm{mg} / \mathrm{L})$. Temperature and $\mathrm{SO}_{4}$ were not correlated for the other grasses or I. missouriensis, $P$. vulgaris, and T. latifolia; although $P$. vulgaris and $T$. latifolia showed a tendency for slight rises in $\mathrm{SO}_{4}$ at low temperatures, concentrations were never significantly greater than for controls.

\section{Discussion}

In unplanted control microcosms, seasonal patterns of microbial processes are not influenced by variation in plant growth and activity and, therefore, mainly reflect the direct effects of temperature and provide a benchmark against which to judge the effects of plants. In the present study and previous research with similar microcosms (Stein et al., 2006), COD removal in controls followed a strong, positive relationship with temperature. While the results presented in Fig. 2 suggest that abrupt changes in COD removal may occur when shifting between warm and cold temperatures, each of the batches sampled were separated by two additional 20-day batches. Data for experiments featuring gradual changes in temperature (i.e. $4^{\circ} \mathrm{C}$ monthly steps) showed gradual, linear changes in COD removal across $4-24{ }^{\circ} \mathrm{C}$, with slight seasonal hysteresis $\left(R^{2}=0.99\right.$ and 0.98 , respectively, for falling and rising temperatures; Stein et al., 2006 and unpublished analyses). Strong temperature dependence is generally assumed for organic matter removal in conventional wastewater treatment systems, and relationships such as the modified Arrhenius equation have been used extensively in treatment wetland design in spite of questions about their appropriateness (USEPA, 2000; Kadlec and Wallace, 2009).

Results for planted microcosms demonstrated that plants generally enhanced year-round average COD removal compared to unplanted controls and that most species negated the seasonal effects of cold temperature observed in controls. Only a few species showed the commonly assumed, negative effects of cold temperature (USEPA, 2000). Current results comprising many species under controlled conditions corroborate previous greenhouse experiments with T. latifolia, S. acutus, and C. utriculata (Stein et al., 2006, 2007) and highlight the significance of plants to cold-season performance. Kadlec and Reddy (2001) and Kadlec and Wallace
(2009) analyzed BOD removal across seasons and temperatures in a large number of operational free water surface and subsurface flow treatment wetlands; they concluded that, on the whole, organic matter removal did not increase at higher temperatures and, not infrequently, declined slightly, as indicated by Arrhenius temperature coefficients less than one. They and others (e.g. USEPA, 2000; Tunçsiper et al., 2009) have advanced several possible explanations for the lack of consistent temperature effects and seasonality including transient storage and turnover of both exogenous and plant-derived organic matter. Our results suggest that plants may play a key role in maintaining high rates of organic carbon removal during the cold, dormant season. The ability of several species to support significantly faster and/or more complete COD removal in winter than summer (C. utriculata and C. nebrascensis in this study; C. utriculata and S. acutus as reported by Allen et al., 2002 and Stein et al., 2006) is potentially valuable because COD removal approached detection limits and could help treatment wetlands meet concentration as well as load-reduction performance criteria.

The capacity to support high organic carbon removal at temperatures as low as $4{ }^{\circ} \mathrm{C}$ indicates that plants, and plant species selection, may be more important in locations with low winter temperatures and extended periods of plant dormancy than in milder climates. Fortunately, performance enhancement by plants appears to be commonplace rather than restricted to certain exceptional species. Many species had consistently high COD removal throughout the year. Except for $S$. acutus, these species are not widely used in treatment wetlands, to our knowledge, and are not well studied. In contrast, $T$. latifolia, $P$. australis, and $P$. arundinacea are widely used and well researched, but they provided less effective treatment than many of the species studied, even allowing for improvements over the course of the study. Because these three species can be invasive in natural wetland ecosystems, and their performance is unexceptional and slow to reach its potential, other species may be preferable in some locations; concerns about invasiveness will be greatest where these species are not naturally a dominant part of the local native vegetation.

The consistently high COD removal rates seen year-round with many species show that they can somehow offset the negative effects of cold temperatures. Elevated $\mathrm{SO}_{4}$ in microcosms during colder temperatures suggest that increased oxygen availability may be a factor. Sulfate reduction and sulfide oxidation are highly sensitive to oxygen, and the high levels of $\mathrm{SO}_{4}$ relative to influent concentrations would not occur without significant amounts of oxygen in the root zone. There was a direct association between species' $\mathrm{SO}_{4}$ responses and their COD removal; the 11 species that showed increased $\mathrm{SO}_{4}$ at lower temperatures also ranked 1-11 for study-averaged COD removal. Study-long average COD and $\mathrm{SO}_{4}$ were strongly related (exponential regression $R^{2}=0.82$ ), as were winter COD and $\mathrm{SO}_{4}\left(R^{2}=0.85\right.$ at $4^{\circ} \mathrm{C}$ in both 2007 and 2008). Redox potential data (not shown) were broadly consistent with these relationships: eight of the nine species with average COD removal $>90 \%$, showed elevated Eh values at low temperatures. Day-6 Eh remained below $-200 \mathrm{mV}$ and was virtually unchanged across seasons in controls and with the majority of plant species. However, readings between $-100 \mathrm{mV}$ and $+200 \mathrm{mV}$ were common with C. bebbii, C. nebrascensis, C. praegracilis, C. utriculata, S. acutus, $J$. arcticus, J. torreyi, and D. cespitosa, and Eh sometimes exceeded $+400 \mathrm{mV}$.

Plants' influence on redox conditions in treatment wetlands could enhance the activities of specific microbial functional groups to promote organic carbon degradation (Faulwetter et al., 2009). Specifically, microbial density and activity have been found to be more abundant on root surfaces and within the rhizosphere (Munch et al., 2005; Gagnon et al., 2007). The steady COD removal and elevated $\mathrm{SO}_{4}$ and $\mathrm{Eh}$ at colder temperature periods may result 
from greater oxygen release by some plant species while respiration is reduced (Stein and Hook, 2005). It is well documented that many wetland species release oxygen from their roots (e.g. Armstrong, 1971; Gries et al., 1990; Sorrell, 1999). Root oxygen loss would be expected to vary among species based on differences in anatomy, morphology, and physiology, and between seasons due to seasonal growth and dormancy cycles (Luxmore et al., 1970; Howes and Teal, 1994; Sorrell et al., 2000).

Conversely, plants add carbon compounds to the root zone as plant detritus and root exudates and may sometimes be an important carbon source in treatment wetlands (Pinney et al., 2000). Plants' carbon input varies seasonally in association with root growth, turnover, and exudation; and their responses to flowering, senescence, herbivory, and other factors (Cheng and Gershenson, 2007). Increased inputs of carbon from plants during the growing season could explain the decreased COD removal at warmer temperatures that was observed with $C$. nebrascensis and $C$. utriculata. Carbon exudates could also contribute to the lower $\mathrm{SO}_{4}$ concentrations seen during warmer temperatures by stimulating sulfate reduction. However, seasonal patterns of plant carbon inputs in wetlands are not well characterized overall, and likely vary considerably among species. Furthermore, $2 \mathrm{~mol}$ of COD is

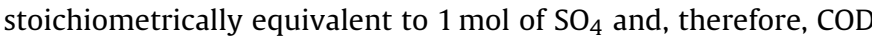
added to microcosms as influent (mainly as organic C) was 35 times in excess of the amount required to completely utilize all sulfate (Stein et al., 2007). Given that the microcosms were overwhelmed with exogenous organic carbon, it is highly unlikely that variation in plant organic carbon release could explain observed variations in sulfate concentrations or, for that matter, residual COD levels. The fact that virtually all sulfate was reduced in both planted and unplanted microcosms at $24^{\circ} \mathrm{C}$ also demonstrates that carbon exudates did not increase sulfate reduction.

Taken together, the seasonal variations in COD removal and $\mathrm{SO}_{4}$ concentrations, and the large excess of COD from wastewater argue that plant effects are more likely from plant oxygen release than organic carbon production. Because domestic wastewater has abundant organic carbon, effective treatment is often limited by oxygen, the most energetically favorable electron acceptor for heterotrophic microorganisms. Enhanced oxygen supply near roots may alleviate this limitation and facilitate more efficient organic carbon removal by aerobic respiration. The prevalence of significant differences between planted microcosms and the unplanted controls during colder temperatures and plant dormancy may result from increased root oxygen loss due to lower respiration (Armstrong, 1971; Moog and Bruggeman, 1998). It is important to note that plant effects depend on hydraulic retention time and COD loading rates (Schultz et al., 2008) and that species effects on COD removal are expected to diminish at shorter batch lengths and/or higher influent COD levels, possibly because plant-mediated oxygen supply is overwhelmed.

\section{Conclusion}

This study showed that the majority of a large and diverse sample of wetland plant species enhanced year-round COD removal compared to gravel-only systems, especially at low temperatures. Certain species performed better than others, whereas a few species provided no appreciable benefit, suggesting that appropriate species selection potentially can increase treatment wetland efficiency throughout the year in cold regions. In general, species of the Cyperaceae (sedge) and Juncaceae (rush) families performed best while most species of the Poaceae (grass) family had poorer performance, with the notable exception of Deschampsia cespitosa, which was one of the top species. While two forbs in the Iridaceae and Lamiaceae families performed poorly, we assessed too few species from these families to allow generalizations. Many of the species with the best year-round and cold-season performance were regionally native and non-invasive and, therefore, may be preferable to some commonly used species for ecological or aesthetic reasons. Overall, our results lend support to the use of the wider range of species that are often recommended (e.g. Wallace and Knight, 2006) but not well researched.

It appears that plant effects on COD removal are related to seasonally varying rhizosphere environmental conditions that mitigate the normal tendency for microbial activity to decline at cold temperatures. Plant influences on seasonal COD removal patterns were associated with two indicators of rootzone oxidation, sulfate concentration and redox potential; species with better wintertime performance and less seasonal variation in COD removal had higher $\mathrm{SO}_{4}$ and $\mathrm{Eh}$ at lower temperatures. Additional research on interactions between microorganisms, plants and temperature in treatment wetlands is needed to improve their design and seasonal operation in cold regions. While further greenhousescale, controlled-environment studies will be valuable for studying wastewater treatment processes, field-scale studies are necessary to evaluate species' performance under realistic conditions and support plant material recommendations. Trials with multi-species plantings merit specific attention, as complex communities may enhance ecosystem functions (Coleman et al., 2001; Picard et al., 2005).

\section{Acknowledgements}

We thank John Neuman and Mark Burr for their technical assistance, Melissa Schroeder and Jill Flores for help in the greenhouse and lab, and David Baumbauer for accommodating our use of the Plant Growth Center for low-temperature research. This study was supported by USDA-NRI Competitive Grants Program, Award 200435102-14832.

\section{References}

Allen, W.C. Hook, P.B., Stein, O.R. Biederman, J.A, 2002. Temperature and wetland plant species effects on wastewater treatment and root zone oxidation. J. Environ. Qual. 31, 1010-1016.

Armstrong, W., 1971. Radial oxygen losses from intact rice roots as affected by distance from apex, respiration and waterlogging. Physiol. Plantarum 25, 192-197.

Bachand, P.A.M., Horne, A.J., 2000. Denitrification in constructed free-water surface wetlands: II. Effects of vegetation and temperature. Ecol. Eng. 14 (1-2), 17-32.

Brisson, J., Chazarenc, F., 2009. Maximizing pollutant removal in constructed wetlands: should we pay more attention to macrophyte species selection? Sci. Total Environ. 407, 3923-3930.

Brix, H., 1997. Do macrophytes play a role in constructed treatment wetlands? Water Sci. Technol. 35, 11-17.

Cheng, W., Gershenson, A., 2007. Carbon fluxes in the rhizosphere. In: Cardon, Z., Whitbeck, J. (Eds.), The Rhizosphere: An Ecological Perspective. Elsevier, Amsterdam, pp. 31-56.

Coleman, J., Hench, K., Garbutt, K., Sexstone, A., Bissonnette, G., Skousen, J., 2001. Treatment of domestic wastewater by three plant species in constructed wetlands. Water Air Soil Poll. 128, 283-295.

Faulwetter, J.L., Gagnon, V., Sundberg, C., Chazarenc, F., Burr, M.D., Brisson, J., Camper, A.K., Stein, O.R., 2009. Microbial processes influencing performance of treatment wetlands: a review. Ecol. Eng. 35, 987-1004.

Gagnon, V., Chazarenc, F., Comeau, Y., Brisson, J., 2007. Influence of macrophyte species on microbial density and activity in constructed wetlands. Water Sci. Technol. 56, 249-254.

Gries, C., Kappen, L., Losch, R., 1990. Mechanism of flood tolerance in reed, Phragmites australis (cav) Trin. ex Steudel. New Phytol. 114, 589-593.

Howes, B.L., Teal, J.M., 1994. Oxygen loss from Spartina-alterniflora and its relationship to salt-marsh oxygen balance. Oecologia 97, 431-438.

Kadlec, R.H., Reddy, K.R., 2001. Temperature effects in treatment wetlands. Water Environ. Res. 73, 543-557.

Kadlec, R.H., Wallace, S., 2009. Treatment Wetlands, second ed. CRC Press, Boca Raton, FL, $1016 \mathrm{pp}$

Kowles-Grove, J., Stein, O.R., 2005. Polar organic solvent removal in microcosm constructed wetlands. Water Res. 39 (16), 4040-4050.

Luxmore, R.J., Stolzy, L.H., Letey, J., 1970. Oxygen diffusion in the soil-plant system. Agron. J. 62, 317-332. 
Moog, P.R., Bruggeman, W., 1998. Flooding tolerance of Carex species. II. Root gasexchange capacity. Planta 207, 199-206.

Munch, C., Kuschk, P., Roske, I., 2005. Root stimulated nitrogen removal: only a local effect or important for water treatment? Water Sci. Technol. 51, 185-192.

Picard, C.R., Fraser, L.H., Steer, D., 2005. The interacting effects of temperature and plant community type on nutrient removal in wetland microcosms. Bioresource Technol. 96, 1039-1047.

Pinney, M.L., Westerhoff, P.K., Baker, L., 2000. Transformations in dissolved organic carbon through constructed wetlands. Water Resour. 34, 1897-1911.

Riley, K.A., Stein, O.R., Hook, P.B., 2005. Ammonium removal in constructed wetland microcosms as influenced by presence and species of plants and organic carbon load. J. Environ. Sci. Health Part A 40 (6-7), 1109-1121.

Schultz, R.L., Stein, O.R., Hook, P.B., 2008. Temperature, plant species and residence time interactions in treatment wetlands. In: Proceedings of the 11th International Conference on Wetland Systems for Water Pollution Control, vol. 1, Indore, India, November 1-7, pp. 161-167.

Sorrell, B.K., 1999. Effect of external oxygen demand on radial oxygen loss by Juncus roots in titanium citrate solutions. Plant Cell Environ. 22, 1587-1593.

Sorrell, B.K., Mendelssohn, I.A., McKee, K.L., Woods, R.A., 2000. Ecophysiology of wetland plant roots: a modeling comparison of a relation to species distribution. Ann. Bot. 86, 675-685.

Stein, O.R., Borden-Stewart, D.J., Hook, P.B., Jones, W.J., 2007. Seasonal influence on sulfate reduction and metal sequestration in sub-surface wetlands. Water Res. 41, 3440-3448.

Stein, O.R., Hook, P.B., 2005. Temperature, plants, and oxygen: how does season affect constructed wetland performance? J. Environ. Sci. Health Part A 40, $1331-1342$.
Stein, O.R., Biederman, J.A., Hook, P.B., Allen, W.C., 2006. Plant species and temperature effects on the $\mathrm{k}-\mathrm{C}^{*}$ first order model for chemical oxygen demand removal in batch loaded ssf wetlands. Ecol. Eng. 26 (2), 100-112.

Stottmeister, U., Wiesner, A., Kuschk, P., Kappelmeyer, U., Kastner, M., Bederski, O., Muller, R.A., Moormann, H., 2003. Effects of plants and microorganisms in constructed wetlands for wastewater treatment. Biotechnol. Adv. 22 93-117.

Tanner, C.C., 2001. Plants as ecosystem engineers in subsurface-flow treatment wetlands. Water Sci. Technol. 44 (11/12), 9-17.

Taylor, C.R., 2009. Selecting plant species to optimize wastewater treatment in constructed wetlands. M.S. thesis. Montana State University, Bozeman.

Tunçsiper, B., Ayaz, S.C.., Akça, L., Gunes, K., 2009. Performance of a pilot-scale, threestage constructed wetland system for domestic wastewater treatment. Environ. Technol. 30 (11), 1187-1194.

USEPA, 2000. Manual: constructed wetlands treatment of municipal wastewaters. EPA/625/R-99/010. National Risk Management Research Laboratory, Office of Research and Development, U.S. Environmental Protection Agency, Cincinnati, Ohio.

U.S. Fish and Wildlife Service, 1988. National list of vascular plant species that occur in wetlands. U.S. Fish and Wildlife Service Biological Report 88 (26.9).

Wallace, S.D. Knight, R.L. 2006. Small-scale constructed wetland treatment systems-feasibility, design criteria, and O\&M requirements. Alexandria, Virginia. Water Environ. Res. Found., 304.

Yang, Q., Chen, Z.H., Zhao, J.G., Gu, B.H., 2007. Contaminant removal of domestic wastewater by constructed wetland: effects of plant species. J. Integr. Plant Biol. 49, 437-446. 